\title{
Contents, Vol. 47, 1985
}

\section{No. 1 Original Paper}

Desmoid Tumor in the Maxillary Sinus: A Case Report

Hasegawa, M.; Nasu, M.; Kamiyama, R.; Fukumoto, T.; Nishijima, W.; Nigauri, T.;

Watanabe, $1 \quad 1$

Efficiency and Limitations of the Upper Airway Mucosa as an Air Conditioner Evaluated from the Mechanisms of Bronchoconstriction in Asthmatic Subjects

Konno, A.; Terada, N.; Okamoto, Y.; Togawa, K 5

Benign Pedunculated Tumours of the Hypopharynx. 3 Case Reports, 1 with Late Malignant

Transformation (with 1 color plate)

Laurent, C; Lindholm, C.E.; Nordlinder, H 17

Hazard to Endotracheal Tubes by CO2 Laser Beam. Experimental Report

Ohashi, N.; Asai, M.; Ueda, S.; Imamura, J.; Watanabe, Y.; Mizukoshi, K 22

Synthesis of Prostaglandin E2 and F2 $\alpha$ in Human Tonsillar Lymphocytes

Morimoto, K.; Shimoda, K.; Kataura, A

A Microbiological Study of Secretory Otitis media Using an Anaerobic Technique

Edström, S.; Ejnell, H.; Jörgensen, F.; Möller, § 32

Speech Discrimination in Advanced Otosclerosis following Stapedectomy

Iurato, S.; Onofri, M 37

Protective Effect of Fosfomycin against Aminoglycoside Ototoxicity

Ohtani, L; Ohtsuki, K.; Aikawa, T.; Sato, Y.; Anzai, T.; Ouchi, J.; Saito, T 42

Quantitative Measurement of Smooth Pursuit Using a Continuously Changing Sinusoidal

Wave in Normal Subjects

Ohashi, N.; Watanabe, Y.; Kobayashi, H.; Mizukoshi, K

49

Announcement

4

No. 2 Original Paper

Formation and Maturation of the Vestibular Ganglion

Anniko, M 57

Computed Tomographic Findings in Ménière's Disease

Nidecker, A.; Pfaltz, C.R.; Matéfi, L.; Benz, U.F 66

Vestibular Training after Sudden Loss of Vestibular Functions

Takemori, S.; Ida, M.; Umezu, H 76

Low Ototoxicity and Its Mechanism of Netilmicin

Ohtani, I.; Ohtsuki, K.; Aikawa, T.; Sato, Y.; Anzai, T.; Ouchi, J.; Saito, T 84

IV Contents

Brain Stem Auditory Evoked Potentials in Patients with the Lateral Medullary (Wallen berg's) Syndrome

Elwany, S 90

Effect of Atropine on the Eustachian Tube Function

Tjernström, Ö.; Andréasson, L.; Groth, P.; Ivarsson, A.; Malm, L 95 
Gustotoxicity of Bleomycin

Soni, N.K.; Chatterji, P

101

Primary Giant Cell Carcinoma of the Larynx. A Clinico-Pathological Study of Four Cases

Ferlito, A.; Friedmann, J.; Recher, G 105

Announcements $\quad 104$

No. 3 Original Paper

Carcinoid Tumors of the Larynx. A Case Study

Guerrier, Y.; Lallemant, J.G.; Charlin, B.; Pages, A 113

Tumor Antigens and Immune Complexes in Laryngeal Cancer

Krajina, Z.; Bolanca, S 119

Complications in Neck Dissection

Olofsson, J.; Tytor, M 123

Oral and Oropharyngeal Cancer, Aryl Hydrocarbon Hydroxylase Inducibility and Smoking.

A Follow-Up Study

Andréasson, L.; Björlin, G.; Laurell, P.; Trell, E.; Korsgaard, R 131

Angiolymphoid Hyperplasia with Eosinophilia of the External Ear (Kimura's Disease)

Ferlito, A.; Caruso, G 139

Plasma Component of Middle Ear Effusion Evaluated by Prekallikrein Level

Hamaguchi, Y.; Sakakura, Y.; Majima, Y.; Ukai, K.; Miyoshi, Y 145

Long-Term Results of Septoplastic Operations

Dommerby, H.; Rasmussen, O.R.; Rosborg, J 151

Comparison of the Adaptation Time Constants of the Vestibulo-Ocular Reflex and of the

Sensation of Rotation during Sinusoidal Stimulation

Rodenburg, M.; Boumans, L.J.J.M.; Maas, AJ.J 158

Book Reviews $\quad 167$

Announcements $\quad 168$

No. 4 Original Paper

A Retrospective Study of Nasopharyngeal Carcinoma Presenting over a 10-Year Period

Milton, CM 169

Chondrometaplasia of the Larynx

Ferlito, A.; Recher, G 174

Surgical Correction of Subglottic Stenosis in Children. A Follow-Up Study

Morimoto, K.; Kobayashi, K..; Shimoda, K.; Enomoto, K.; Kataura, A 178

Treatment of Auricular Hematoma Using Button Technique

Talaat, M.; Azab, S.; Kamel, T 186

Submucosal Diathermy of the Inferior Turbinate and the Congested Nose

von Haacke, N.P.; Hardcastle, P.F 189

Contents

$\mathrm{V}$

Recovery of Vestibulospinal Balance Function after Unilateral Labyrinthectomy in Patients with Ménière's Disease

Kaga, K.; Takemori, S.; Suzuki, J 194

Vestibular Neuronitis: Neurotological Findings and Progress

Matsuo, T.; Sekitani, T

199

Correlation between Vestibular and Cochlear Measures in Internal Ear Disorders

Tsalighopoulos, M.G.; Chalabi, Z 207 
Nasal Mucosal Blood Flow in Atrophic Rhinitis

Bende, M 216

Immunoglobulin E in Mucoid Secretory Otitis Media

Palva, T.; Lehtinen, T.; Halmepuro, L 220

Book Reviews 224

No. 5 Original Paper

Microvasculature of the Stria vascularis in the Round Window Area in the Rat. A Scanning Electron Microscopy Study

Tange, R.A.; Hodde, K.C 225

Reduction of Cisplatin Ototoxicity by Fosfomycin in Animal Model

Ohtani, I.; Ohtsuki, K.; Aikawa, T.; Anzai, T.; Ouchi, J.; Saito, T 229

Impairment of the Chick's Grip and Balance by Streptomycin. A Preliminary Study

Cohen, G.M.; Park, J.C 236

Statoconia Displacement in Squirrel Monkey Ears

Ohashi, K.; Igarashi, M 242

Diagnostic Value of Velocity-Step Responses

Huygen, P.L.M.; Nicolasen, M.G.M 249

The Value of Carbamazepine in the Treatment of Tinnitus

Hulshof, J.H.; Vermeij, P 262

The Nasal Local Antibody Production of Rats against Respiratory Infections

Okamoto, Y.; Konno, A.; Togawa, K.; Amano, Y 267

Nasal Fractures in Children - Long-Term Results

Dommerby, H.; Tos, M 272

Short Communication

Adverse Reaction to Locally Applied Preservatives in Nose Drops

Hillerdal, G 278

Book Reviews 280

Announcement 280

No. 6 Original Paper

Effect of Urea on Endolymphatic Hydrops in Guinea Pigs

Yazawa, Y.; Shea, J.J 281

Basal Lamina Pathology of the Utricle and Endolymphatic Duct in Ménière's Disease

Fitzgerald O'Connor, A.F.; Bagger-Sjöbäck, D.; Friberg, U.; Rask-Andersen, H 288

Auditory Brain Stem Response in Neuropathological Mutant Mice (Shiverer and Reeler)

Kanzaki, J.; Mikoshiba, K.; Tsukada, Y 294

VI

Contents

Repair of Stenosed Tracheostoma

Takato, T.; Ono, I.; Ebihara, S.; Saeki, T

Treatment of Perennial Secretory Rhinitis

Bende, M.; Rundcrantz, H 303

Cholinergic Muscarinic Receptor in the Nasal Mucosa of Guinea Pigs with Bronchial

Asthma with and without Hypersensitive Nasal Symptoms

Konno, A.; Terada, N.; Okamoto, Y 307

Quantitative Measurement of Smooth Pursuit Using the Continuously Changing Sinusoidal Wave in Neurological Patients 
Ohashi, N.; Watanabe, Y.; Kobayashi, H.; Mizukoshi, K 314

Announcements $\quad 306$

Author Index 328

Subject Index 329

Fig. 1. Pedunculated hypopharyngeal tumour measuring $20 \times 5 \mathrm{~cm}$ (case 1).

Fig. 2. The base of the hypopharyngeal fibroli-poma in case 1 , located on the outside of the right aryteno-epiglottic fold and on the postero-lateral external aspect of the cricoid cartilage.

Fig. 3. Histopathology of the fibrolipoma in case 1. Van Gieson. X 120.

Fig. 4. Appearance of the hypopharynx and larynx in case 1 after removal of the base of the fibrolipoma through a right-sided lateral pharyngotomy.

Fig. 5. Histopathology of the benign fibromatous tumour in case 3 shown in figure 6 . Van Gieson. $\times 120$.

Fig. 7. The smaller hypopharyngeal tumour at the posterior aspect of the left arytenoid region and the larger broad-based right-sided tumour partly obscured by the endotracheal tube. Fig. 8. Histopathology of the right-sided tumour in case 3, consistent with a malignant fibrous histiocy-toma grade II. Malignant transformation was observed after 20 years at the same site as the fibromatous tumour seen in figure 5 .

Fig. 9. End result in case 3, with the scar after removal of the malignant hypopharyngeal fibrous his-tiocytoma through a right lateral pharyngotomy. (En-doscopic photography with StorzHopkins equipment, provided by AB Stille Werner, Stockholm.) 